\title{
PENERAPAN SANKSI TERHADAP PELANGGARAN AWIG-AWIG DI DESA ADAT BONGKASA PERTIWI KECAMATAN ABIANSEMAL KABUPATEN BADUNG
}

\author{
A.A. Dwi Ani Agustini, I Made Suwitra, I Ketut Sukadana \\ Fakultas Ilmu Hukum Universitas Warmadewa, Denpasar-Bali, Indonesia \\ Junkany71@gmail.com, Madesuwitra27@gmail.com, Sukadana.fhunwar@gmail.com
}

\begin{abstract}
Abstrak
Manusia selalu hidup berdampingan dan membutuhkan makhluk lainya untuk berinteraksi satu sama lainnya. Mereka diciptakan sebagai makhluk sosial yang tidak bisa hidup sendiri Penelitian ini bertujuan untuk menganalisis eksistensi ngejot serta penerapan sanksi terhadap pelanggarannya di Desa Adat Bongkasa Pertiwi. Jenis penelitian ini menggunakan tipe penelitian hukum empiris dengan pendekatan sosiologis, pendekatan melalui perundang-undangan, konsep dan pendekatan kasus. Data dalam penelitian ini berupa data primer yaitu data yang diperoleh dari informan maupun responden dan data sekunder yang menggunakan bahan hukum primer, sekunder dan tersier. Hasil penelitian menunjukkan bahwa eksistensi ngejot di Desa Adat Bongkasa Pertiwi Kecamatan Abiansemal Kabupaten Badung saat ini melarang adanya tradisi ngejot. Ngejot masih menjadi pro dan kontra di masyarakat karena ngejot terkadang masih dilaksanakan sebagai bentuk (menyama braya). Seiring berjalannya waktu, larangan ngejot dapat berubah dan disesuaikan dengan keadaan karena sifatnya fleksibel. Berkenaan dengan sanksi terhadap larangan ngejot di Desa Adat Bongkasa Pertiwi, dapat diancam berupa (denda) Rp. 1.000 .000 (satu juta rupiah), bass apikul (100 kg) dituntut menjadi sinoman selama 6 bulan dan meminta maaf di hadapan masyarakat Desa Bongkasa Pertiwi. Sekalipun pelaksanaan ngejot ini dilakukan hanya sebatas ngejot aci untuk kelengkapan upacara, namun harus berdasarkan izin melalui Bendesa Adat.
\end{abstract}

Kata Kunci: Awig-awig, Desa Adat Bongkasa Pertiwi, Ngejot, Penerapan sanksi.

\section{Abstract}

Humans always live side by side and need other creatures to interact each other. They were created as social beings who cannot live alone. This research aims to analyze the existence of ngejot and the application of sanctions for violations in the Bongkasa Pertiwi Traditional Village. This type of research uses an empirical legal research with a sociological approach, a statutory approach, a concept approach and a case approach. The data in this study are primary data, namely data obtained from informants and respondents and secondary data using primary, secondary and tertiary legal materials. The results showed that the existence of ngejot in the Bongkasa Pertiwi Traditional Village, Abiansemal District, Badung Regency, currently prohibits the existence of the tradition of ngejot. Boosting is still a pro and contra in society because pushing is sometimes still practiced as a form (equalizing braya). Over time, the prohibition on driving can change and be adapted to the circumstances because it is flexible. With regard to the sanctions against the prohibition of boasting in the Bongkasa Pertiwi Traditional Village, a penalty of Rp. 1,000,000 (one million rupiah), apikul bass (100 kg) were required to be sinoman for 6 months and apologized in front of the people of Bongkasa Pertiwi Village. Even though the implementation of this ngejot is carried out only to the extent of ngejot aci for the completeness of the ceremony, it must be based on permission through Bendesa Adat.

Keywords: Awig-awig, Bongkasa Pertiwi Traditional Village, Ngejot, Implementation of sanctions. 


\section{PENDAHULUAN}

Manusia selalu hidup berdampingan yang membutuhkan makhluk lainya untuk berinteraksi satu sama lainnya. Mereka diciptakan sebagai makhluk sosial yang tidak bisa hidup sendiri. Manusia bebas memiliki hubungan dengan yang lainnya namun kebebasan tersebut harus berdasarkan hukum yang mengatur untuk membatasi serta menghindari permasalahan dalam kesepakatan yang mereka sepakati (Hajati et al., 2017). Kehidupan manusia selalu diatur oleh hukum, bahkan di Indonesia tercermin sebagai negara keberagaman hukum yang disebut pluralitas. Yang mengakui adanya hukum barat, hukum agama maupun hukum adat. Kenyataan hukum adat masih dipakai oleh masyarakat untuk mengatur kehidupan bersosial di lingkungan masyarakat (Manarisip, 2012; Mustari, 2014).

Hukum adat yang merupakan aturan terbawah yang mengatur kehidupan masyarakat tradisional yang mengedepankan keharmonisan, pengaturan ini sudah diakui secara hukum nasional melalui Undang-Undang Dasar Negara Republik Indonesia Tahun 1945 (selanjutnya yang disebut UUD RI 1945) yang pengakuannya tertera dalam norma dasar yaitu pasal 18B Ayat (2) dan pasal 28I Ayat (3) disebutkan dengan jelas (Ketut, 2016; Susylawati, 2009). Merujuk pada kehidupan masyarakat di Bali memiliki pengaturan nya sendiri yang dapat disebut sebagai awig-awig. Dalam awig-awig memuat hak dan kewajiban serta terdapat pengaturan sanksi didalamnya. Sanksi sebagai hukuman atas penebusan kesalahan baik yang dilakukan dengan sengaja maupun tidak sengaja. Dalam sanksi memuat akibat serta mengacu pada pemulihan atas apa yang telah diperbuat. Penerapan sanksi bertujuan untuk memunculkan perubahan perilaku seseorang terhadap pelanggaran yang telah dilakukannya (Harahap, 2006; Soleman, 1987). Sama seperti adanya awig-awig dalam satu kesatuan Desa Adat sebagai pengaturan di lingkungan dalam melaksanakan hak dan kewajiban tersebut, maka dari itulah dibutuhkan penerapan sanksi terhadap pelanggaran dalam Desa Adat. Dalam penerapan sanksi sebagai pelanggaran awig-awig desa adat berkaitan dengan adanya suatu larangan ngejot di Desa Adat Bongkasa Pertiwi Kecamatan Abiansemal Kabupaten Badung yang masih menjadi pro dan kontra di masyarakat karena terkadang masih dilaksanakan sebagai bentuk hubungan harmonis (menyama braya) yang sudah jelas adanya suatu pelanggaran dalam aturan larangan ngejot.

Berdasarkan uraian di atas, maka penelitian ini dirumuska untuk mengetahui eksistensi ngejot di Desa Adat Bongkasa Pertiwi Kecamatan Abiansemal Kabupaten Badung, dan untuk mengetahui penerapan sanksi terhadap pelanggaran larangan ngejot di Desa Adat Bongkasa Pertiwi Kecamatan Abiansemal Kabupaten Badung.

\section{METODE PENELITIAN}

Metode penelitian ini menggunakan tipe penelitian hukum empiris, aspek hukum empiris ini bertujuan untuk mengungkapkan keadaan hukum dalam kehidupan nyata di masyarakat (Soekanto \& Memudji, 2003). Pendekatan masalah yang digunakan dalam penelitian ini adalah pendekatan sosiologis, pendekatan melalui perundang-undangan, konsep dan pendekatan kasus. Permasalahan yang akan dikaji berkaitan dengan penerapan sanksi terhadap pelanggaran awig-awig di desa adat serta penyelesaiannya. Sumber data dalam penelitian ini menggunakan data primer yang diperoleh langsung dari informan maupun responden. Bahan Hukum Primer meliputi Undang-Undang Dasar 1945, Peraturan Daerah Provinsi Bali Nomor 4 tahun 2019 tentang Desa Adat di Bali dan awigawig Desa Adat Bongkasa Pertiwi Kecamatan Abiansemal Kabupaten Badung, Bahan hukum Sekunder meliputi buku-buku hukum serta jurnal-jurnal hukum dan Bahan Hukum Tersier meliputi Kamus Basa Bali.

\section{HASIL DAN PEMBAHASAN}

\section{Eksistensi ngejot di Desa Adat Bongkasa Pertiwi Kecamatan Abiansemal Kabupaten Badung}

Dalam Kamus Basa Bali Wiki, konsep ngejot berakar dari kata Jot atau Ejot yang artinya mengirim makanan kepada teman. Ngejot merupakan suatu bentuk tradisi memberikan makanan kepada para tetangga sebagai bentuk ungkapan terima kasih. Tradisi ngejot ini sebagai kerukunan atau menyama braya simbol kemesraan dan tali persaudaraan antar sesama manusia. Mengingat manusia hidup saling berdampingan dan merupakan makhluk sosial, saling membutuhkan satu sama lainnya, yang menjalin hubungan yang harmonis sesama antar umat maupun tetangga. Mengenal istilah ngejot di Desa Adat Bongkasa Pertiwi Kecamatan Abiansemal Kabupaten Badung yang dijelaskan oleh I Wayan Supartana selaku Bendesa Adat Bongkasa Pertiwi memberikan penjelasan mengenai ngejot: 
"segala bentuk suguhan makanan, maupun menerima atau memberi ejotan makanan saji atau ejotan dalam bentuk apapun".

Menurut Bendesa Adat Bongkasa Pertiwi Bapak I Wayan Supartana di Desa Adat Bongkasa Pertiwi dahulunya pernah melaksanakan tradisi ngejot. Biasanya tradisi ngejot ini dilaksanakan saat Upacara keagamaan maupun Upacara Manusa Yadnya. Dalam upacara biasanya krama (masyarakat) sudah menghabiskan dana yang cukup banyak ditambah lagi krama harus melakukan ngejot kepada tetangga maupun sanak keluarga. Otomatis dana yang dikeluarkan juga bisa melebihi bahkan dibilang tidak sedikit. dari sinilah permasalahan muncul, beberapa krama yang kurang mampu merasa keberatan melaksanakan ngejot. Ngejot dianggap memberatkan karena akan memerlukan biaya yang lebih saat krama menjalankan suatu acara tertentu dan harus diberatkan lagi dengan melakukan ngejot. Selain memberatkan dari segi materi juga memberatkan dari segi fisik yaitu tenaga, akan membuat krama yang mempunyai acara tertentu merasa berat serta ribet untuk membagikan ejotan kepada tetangga karena waktunya akan habis dalam proses ngejot ini dilakukan. Penetapan larangan ngejot ini dilaksanakan untuk mewadahi krama khususnya yang kurang mampu agar tidak dibedabedakan status sosialnya menghindari rasa tidak enak, dianggap tidak mampu untuk menyama braya melalui ngejot. Jika dilihat dari status sosial ada yang mampu untuk melaksanakan ngejot dan ada yang tidak, dari keluhan inilah, melalui sangkepan desa adat dibuatnya suatu aturan larangan ngejot untuk mewadahi krama kurang mampu agar tidak merasa dibedakan.

Bentuk praturan ini dibuat pada tahun 2010 dan telah ditetapkan adanya suatu awig-awig dalam bentuk pelaksanaan berupa pararem penyahcah awig. Pemberlakuan larangan ini dibuat berdasarkan keputusan sangkepan Krama (masyarakat) Desa Adat Bongkasa Pertiwi serta prajuru-prajuru adat yang diambil dari keinginan krama (masayarakat) yang telah disepakati serta dijalankan sesuai situasi dan kondisi. Pemberlakuan larangan ini tidak tertulis dalam awig-awig Desa Adat Bongkasa Pertiwi dikarenakan sifatnya yang fleksibel, sewaktu-waktu akan berubah sesuai keadaan saat itu, serta larangan ngejot ini tidak tertulis dalam awig-awig karena sifat larangan ini tidak dalam artian merusak, penganiyayaan, maupun pelanggaran hukum lainnya, maka dari itualah aturan ini dibuat dan ditegakkan serta dijalankan hingga saat ini berdasarkan keputusan sangkepan Desa sebagai awig-awig namun tidak berbentuk tertulis. Hingga saat ini eksistensi larangan ngejot di Desa Adat Bongkasa Pertiwi masih dilaksanakan. Berkaitan dengan berjalannya waktu larangan ngejot ini bisa saja berubah sesuai keadaan yang berlaku karena sifatnya yang fleksibel bisa berubah sewaktu-waktu sesuai keadaan saat itu. Berdasarkan wawancara ini diambil pada tanggal 26 Oktober 2019 di kediaman bapak I Wayan Supartana (Bendesa Adat Bongkasa Pertiwi).

Berdasarkan tanggapan beberapa masyarakat Desa Bongkasa Pertiwi mengenai adanya larangan ngejot, Gusti Ayu Putri Supartini (Krama Adat) mengatakan bahwa dengan keberadaan larangan ngejot dapat meringankan, tidak perlu kesana-kemari untuk ngejot, serta pengeluaran juga sedikit, untuk mengatasi rasa tidak enak karena tidak bisa ngejot digantikan agar makan dirumah saat acara berlangsung. Sedikit tidaknya rasa kebersamaan menyama braya itu masih ada. I Wayan Wanta (Ketua Pecalang Desa Bongkasa Pertiwi) mengatakan bahwa beliau membenarkan bahwa pernah mendapat ejotan dari orang yang mempunyai karya (Upacara), beliau diberikan ejotan karena diminta untuk ikut serta dalam membantu kelancaran dalam upacara tersebut, mengingat adanya larangan ngejot Bapak I Wayan Wanta selaku Ketua Pecalang Desa juga sudah mengkonfirmasi terkait izin ngejot ini oleh Bendesa Adat berdasarkan kepentingan untuk kelancaran upakara yang ejotan ini dimaknai ejotan aci atau simbolis suatu upacara.

\section{Penerapan Sanksi terhadap Pelanggaran Larangan ngejot di Desa Adat Bongkasa Pertiwi Kecamatan Abiansemal Kabupaten Badung}

Sanksi merupakan suatu bentuk hukuman yang didalamnya terdapat balasan akibat perilaku yang merugikan baik itu sengaja maupun tidak. Balasan akibat tindakan ini merupakan bentuk perubahan tingkah laku agar pelanggaranya menyesali dan sebagai pelajaran untuk merubah perilaku untuk kedepannya menjadi lebih baik lagi. Hukuman dalam sanksi ini bertujuan untuk memberikan rasa kapok, sadar, jera maupun memaksa pelanggarnya untuk tidak melakukan kesalahan lagi serta membuat pelanggarnya dengan otomatis mematuhi aturan sebagaimana mestinya. Sanksi dapat sebagai pengikat dan patokan dalam mencapai peraturan yang lebih baik dalam pemerintahan dan kemasyarakatan. Serta sanksi juga memberikan rasa adil tentram dan damai jika selaras tidak adanya 
penyimpangan. Dilihat dalam jenisnya sanksi dalam awig-awig yang ditegaskan dalam Paos 97 indik pamidanda dalam awig-awig Desa Adat Bongkasa Pertiwi yang berbunyi sebagai berikut:

1. Bebacakan pamidanda sane kemanggeh tri danda luire:

ha. Arta danda, tegesipun kadanda antuk jinah;

na. Dewa danda, tegesipun kadanda antuk pengaskara utawi bebanten;

ca. Jiwa danda, tegesipun kadanda antuk ring banjar utawi desa wiadin kepatutanipun nunas pengampura.

2. Jiwa utawi artha brana pemidandanya dados druwen banjar utawi desa.

3. Anak alit sadurung maketus utawi durung mayusa 10 tahun luput saking dedendan.

Arti bebasnya sebagai berikut:

1. Pembagian jenis sanksi terbagi menjadi tiga yaitu:

a. sanksi bernilai ekonomi, denda berupa uang;

b. sanksi yang ditujukan kehadapan tuhan, dikenakan denda banten atau yadnya;

c. sanksi kejiwaan, dikenakan denda di banjar atau desa dan meminta maaf.

2. Kekayaan denda dimiliki oleh banjar atau desa.

3. Anak kecil yang belum genap berusia 10 tahun lepas dari denda.

Penerapan sanksi ini bertujuan untuk mengubah tindakan dan pola pikir agar pelanggarnya merasa kapok, dengan demikian pelanggar akan berpikir terlebih dahulu sebelum melakukan sesuatu dalam tindakannya. Sepanjang aturan tetap ditaati kepatuhan terhadap aturan hukum maka tidak akan adanya suatu pelanggaran. Namun rendahnya kesadaran hukum masyarakat tidak menutup kemungkinan masih terjadi suatu pelanggaran. Oleh karena itulah perlunya penerapan sanksi yang berlaku untuk seseorang yang telah melanggar suatu aturan. Seperti halnya di Desa Adat Bongkasa Pertiwi menetapkan penerapan sanksi terhadap adanya pelanggaran awig-awig.

Menurut Bapak I Wayan Supartana selaku Bendesa Adat di Desa Adat Bongkasa Pertiwi. Telah ditetapkan adanya suatu awig-awig dalam bentuk pelaksanaan berupa pararem penyacah awig yang telah ditetapkan dalam sangkepan Desa Adat Bongkasa Pertiwi oleh Prajuru Adat di Desa Bongkasa Pertiwi. I Wayan Supartana menegaskan, berjalannya awig-awig ini, tidak tercantum tertulis dalam awig-awig maupun pararem karena sifatnya yang fleksibel, sewaktu-waktu akan berubah menyesuaikan keadaan. Selain itu, tidak ditulisnya awig-awig ini secara tertulis dikarenakan larangan ini tidak bersifat pelanggaran hukum yang mengakibatkan merusak, penganiyaayaan maupun pelanggaran hukum lainnya. Larangan ngejot ini hanya sebatas wadah untuk mengatasi permasalahan Krama (masyarakat) yang kurang mampu untuk ngejot agar terhindar dari pandangan status sosial yang membedakan Krama (masyarakat) dalam mampu atau tidaknya melaksanakan tradisi ngejot di Desa Adat Bongkasa Pertiwi. Pemberlakuan Larangan ini berdasarkan kesepakatan-kesepakatan dalam sangkepan oleh Prajuru Adat serta masyarakat Desa Adat Bongkasa Pertiwi. Jika terjadinya suatu pelanggaran Awig-awig terhadap Larangan ngejot ini yang dilakukan oleh krama (masyarakat) Desa Adat Bongkasa Pertiwi, telah ditetapkan, sanksi sebagai berikut:

1. Dikenakan sanksi berupa dedosan (denda) sebesar Rp. 1.000.000,00 (satu juta rupiah)

2. Baas apikul (beras $100 \mathrm{~kg}$ );

3. Ngayah di Pura menjadi sinoman selama kurun waktu 6 (enam) bulan;

4. Mengolas-olas (minta maaf).

Penerapan sanksi terhadap pelanggaran ngejot ini terkadang tidak berjalan mulus, adanya suatu kendala dalam penerapan sanksi awig-awig Desa Adat Bongkasa Pertiwi dalam eksistensi ngejot. Menurut Bapak I Wayan Supartana selaku Bendesa Adat, kendala yang dihadapi dalam pelaksanaan larangan ngejot ini, menimbulkan perasaan tidak enak dalam penerapan sanksi ngejot. Rasa tidak enak ini muncul ketika beliau selaku orang pertama yang akan didatangi untuk dimintai izin jika sewaktu-waktu ada upacara adat yang secara terpaksa harus melaksanakan ngejot sebagai ngejot aci untuk kelengkapan upacara. Ngejot aci tersebut biasanya sebagai kelengkapan sesajen yang diperlukan untuk diberikan kepada pemangku. Selain itu, dalam suatu persiapan upacara membutuhkan bantuan tenaga dari orang lain seperti kerabat dekat atau tetangga terdekat untuk membantu mempersiapkan upakara dalam suatu karya (upacara) tertentu. Tidak mungkin bila seseorang yang mempunyai suatu upacara mengundang kerabatnya hanya untuk membantu dalam proses persiapan upacara dari awal sampai akhir. Pastilah adanya suatu hubungan timbal baliknya. Realistis saja, siapa yang ingin dipekerjakan tapi tidak dapat imbalan. Maka dari itu, seseorang yang mengundang kerabatnya untuk ngidih pekaryan (meminta bantuan suatu pekerjaan) kepada 
kerabatnya. Pastilah tidak enak jika tidak ada tindakan timbal baliknya untuk mengungkapkan rasa terima kasih dengan bentuk ngejot.

Maka dari inilah seseorang pemilik Karya (upacara) biasanya akan meminta ijin untuk agar bisa diberi kebijakan suatu ijin agar proses upacara yang akan berlangsung dapat berjalan sebagaimana mestinya dan tidak ada hambatan dalam pelaksanaan upacara tersebut. Keadaan seperti inilah Bendesa Adat kadang merasa mendapatkan kendala dalam menegakkan awig-awig dalam Larangan ngejot. Dimana bertentangan dengan dengan awig-awig yang ada namun keadaan memaksa untuk melakukan ngejot tersebut. Bapak I Wayan Supartana selaku Bendesa Adat Desa Bongkasa Pertiwi mengatakan" dengan beliau memberikan izin dalam melaksanakan ngejot tidak mengurangi rasa hormat terhadap aturan yang ada, dimana Bapak I Wayan Supartana menjelaskan kembali bahwa aturan Larangan Ngejot ini dibuat dan ditetapkan untuk menentramkan warganya khususnya Krama (warga) yang kurang mampu agar tidak merasa diberatkan dan dibedakan status sosialnya".

Tujuan aturan ini dibuat untuk keharmonisan warganya dan mencapai suatu ketentraman atau kerukunan di lingkungan krama desa. Dengan mendapatkannya ijin untuk melakukan ngejot dengan catatan tidak adanya paksaan, tuntutan, atau merasa terbebani sebab melakukan ngejot atas keinginan yang bersangkutan serta dikatakan sudah mampu untuk merasa suka rela dalam melaksanakan ngejot tersebut. Dengan memberikan ijin untuk melaksanakan ngejot atas dasar pemuput karya. Bendesa Adat menyerahkan tanggungjawab sepenuhnya kepada pihak yang memiliki Upacara jika sewaktuwaktu ada masalah merasa keberatan, Bendesa Adat tidak ikut serta bertanggungjawab atas kerugian yang sudah dialami. Karena saat meminta ijin dalam pelaksanaan ngejot dirasa mampu dan siap menanggung apapun resikonya. Karena Bendesa Adat dirasa sudah cukup bijak dalam mempertimbangkan segala sesuatunya dalam memberikan suatu ijin melaksanakan ngejot yang jelasjelas sudah ada kebijakan awig-awig yang melarang adanya suatu larangan ngejot di Desa Adat Bongkasa Pertiwi Kecamatan Abiansemal Kabupaten Badung. Berdasarkan wawancara ini diambil pada tanggal 26 Oktober 2019 di kediaman bapak I Wayan Supartana (Bendesa Adat Bongkasa Pertiwi).

\section{SIMPULAN DAN SARAN}

\section{Simpulan}

Berdasarkan pembahasan yang dikemukakan di atas, dapatlah disimpulkan bahwa eksistensi ngejot di Desa Adat Bongkasa Pertiwi Kecamatan Abiansemal Kabupaten Badung saat ini melarang adanya tradisi ngejot. Keberadaan ngejot masih menjadi pro dan kontra dimasyarakat karena ngejot terkadang masih dilaksanakan sebagai bentuk hubungan yang harmonis (menyama braya). Berjalannya waktu larangan ngejot dapat berubah menyesuaikan keadaan karena sifatnya yang fleksibel. Kemudian, penerapan sanksi larangan ngejot di Desa Adat Bongkasa Pertiwi melarang adanya tradisi ngejot, sekalipun tradisi ini dilaksanakan hanya sebatas ngejot aci sebagai kelengkapan upacara serta harus berdasarkan ijin terlebih dahulu. Serta jika tidak sesuai dengan ijin pelaksanaan ngejot dapat dikenakan sanksi berupa dedosan (denda) Rp. 1.000 .000 (satu juta) rupiah, baas apikul (100 kg), dituntut menjadi sinoman selama 6 (enam) bulan, dan diminta untuk meminta maaf di hadapan krama (masyarakat) Desa Adat Bongkasa Pertiwi.

\section{Saran}

Mengingat penerapan sanksi awig-awig Desa Adat terhadap pelanggaran oleh Krama Desa Adat Bongkasa Pertiwi Kecamatan Abiansemal Kabupaten Badung, maka hendak disampaikan beberapa saran yakni, mengingat dalam penetapan larangan ngejot sebaiknya harus mendengar keinginan masyarakat agar tidak terjadinya kesenjangan norma pada aturan larangan ngejot. Kemudian, kepada Prajuru Adat (Bendesa Adat Bongkasa Pertiwi), sebaiknya dalam membuat kebijakan lebih dipertimbangkan lagi agar tidak mengatur kebijakan yang cuma-cuma.

\section{DAFTAR PUSTAKA}

Hajati, S., Poespasari, E. D., \& Moechthar, O. (2017). Buku Ajar Pengantar Hukum Indonesia. Airlangga University Press.

Harahap, Z. (2006). Pengaturan Tentang Ketentuan Sanksi Dalam Peraturan Daerah. Jurnal Hukum IUS QUIA IUSTUM, 13(1), 38-49.

Ketut, W. I. (2016). Kedudukan Desa Adat dalam Sistem Ketatanegaraan. Kalimetro Inteligensia. 
Manarisip, M. (2012). Eksistensi Pidana Adat dalam Hukum Nasional. Lex Crimen, 1(4), 24-40. Mustari, S. (2014). Hukum Adat Dahulu, Kini, dan Akan Datang. Prenadamedia Group.

Soekanto, S., \& Memudji, S. (2003). Penelitian Hukum Empiris. UI Press.

Soleman. (1987). Hukum Adat Suatu Pengantar Awal dan Prediksi Masa Mendatang. PT.Eresco.

Susylawati, E. (2009). Eksistensi Hukum Adat Dalam Sistem Hukum di Indonesia. Al-Ihkam, 4(1), $124-140$. 